\title{
The Forecasting Plant Trend That Is Appropriate in the Storage of Carbon Dioxide to Fight Global Warming in the Area of Nonthaburi
}

\author{
C. Vanlisuta
}

\begin{abstract}
This research paper is aimed at developing a mathematical model to determine species and number of plants to be grown in a plot of land to establish forest in the CDM (clean development mechanism) project. Previously, tree planting aiming to reduce carbon in the atmosphere was unsystematically designed and it is usually based on self preference or available seeds on-hands. As a result, a total carbon absorption by the plants is not according to the requirement. Thus, a 0-1 integer programming is developed to solve the mentioned problem. The developed mathematical model therefore provides the optimal solution that ensures required amount of carbon sequestration from the trees and also obtains maximum profit determining between carbon credit revenue and expenses from tree planting. The developed model is flexible enough to allow users to specify amount of required carbon sequestration or even a number of certain plants needed to grow. In addition, the model is also taken into account efficient planting pattern with mixture stand to avoid competition among planting trees. The numerical results show the practical solutions which are verified by experts. In brief, the developed mathematical model is useful for forest establishment project as it provides both systematic design and optimal solution in terms of expected carbon absorption.
\end{abstract}

Index Terms - Integer programming, optimization, CDM, climate change, carbon sequestration, tree planting.

\section{INTRODUCTION}

Reforestation is one solution in reducing amount of carbon dioxide, but found on the other hand that the forests in Thailand have been decreased and the current form of reforestation has been wrong direction and lacking in principles. Mostly, the reforestations have been done under granted environments and never taken into account of maximum output. Thus, they need to have a form of tree planting properly and conform with their ability to absorb carbon dioxide for maximum benefits. From mathematic model research to find out the most possible and beneficial results, such as [1] the study of Solving Environmental Problems with Integer Programming Recent Experience and Challenges by applying the mathematic model to find out the solution. $[2,3,4]$ So, the objective of this project is to build the mathematic model for finding out a proper point of kind and quantity of trees to plant in one unit area in order to

Manuscript received June 18, 2013, revised July 30, 2013.

C. Vanlisuta is with the Department of Production Engineering Phranakhon Rajabhat University, Bangkok, Thailand (e-mail: c_vanlisuta@yahoo.com). reduce the amount of carbon dioxide to the required amount with best economic benefit through Linear Integer Programming.

\section{PROBLEM DESCRIPTION}

Nowadays global warming due to carbon emission in the atmosphere is one of the most intimidating problems in the world. The United Nations attempt to reduce emission of greenhouse gases (GHG) through Kyoto mechanisms named, emissions trading, CDM, and joint implementation.[5,6] The methodologies implemented and recommended by United Nations Framework Convention on Climate Change (UNFCCC) include mitigation of greenhouse gases, reducing emissions from deforestation and forest degradation in developing countries (REDD), land use, land-use change and forestry (LULUCF), emissions resulting from fuel used for international transportation: aviation and marine etc. [7,8]

As mentioned earlier that one of the methodologies to reduce GHG is to increase forest as a sink process to absorb carbon in the atmosphere. Many nations design green policies and persuade private sectors to support sustainable development. One of the pertinent and direct methods is forestry by planting more trees and increase forest areas. However, effective tree planting knowledge is not prevalent among people and only a few of them are aware of different carbon sequestration capability by trees. Meaning that most of the tree growers attempt and compete by number of trees successfully planted instead of total amount of carbon absorption obtained. As a result, trees are unsystematically planted without pattern and good practice. As a matter of fact tree planting is deemed both science and art which it requires a good combination of engineering and social science to obtain successful result. In other words, one must determine tree species or types, tree planting pattern and number of each tree species to be planted at each position to fill the land in order to attain required carbon absorption and moreover one should also optimize costs and revenue. It is due to the fact that once planted it will take years to be grown up. If wrong decision is made, the process is not easily reversible and GHGs are inadvertently released to the atmosphere if trees are uprooted and replanted.[9] Therefore, it is obvious that this problem is crucial and worthwhile to conduct in-depth research. In addition, making a decision of which and how many trees must be planted in one area is unique, difficult and it is not possible to obtain optimal solution without an aid of a mathematical model. However, this problem can be achieved by a linear integer programming method through a 
formulation of an objective function and constraints. [10] With this method all factors can be simultaneously considered and the optimal solution with maximum objective value can be ensued. Details of mathematical model formulation and description will be elaborated next.

\section{Methodology}

\section{A. Mathematical Formulation}

The objective of this research as mentioned earlier is to develop a mathematical model to determine an optimal number and species of trees planting in the forest in order to attain required carbon absorption. The mathematical technique named an integer linear programming is attempted to solve the problem. Thus, a mathematical model which is consisted of the objective function and a bunch of constraints must be established and can be described as the following. .

\section{1) Objective function}

The objective function is the ultimate decision goal of the model. This function compares among alternative decision variables and then selects the optimal and feasible solution which tends to maximize or minimize the result. The objective function will normally be cost or any measurable quantitative attributes function. In this case, the revenue function which is the different between plant and operation expenses and profit earned from carbon trading is defined and utilized. It is due to the fact that expenses incurred in tree planting are seeding costs, labor costs for land preparation, operation and maintenance cost. On the other hands, the only revenue from this afforestation is carbon credit trading since the deforestation or logging will never be considered in terms of environmental point of view.

Target Equation

Maximize

$$
Z=\sum_{i=1}^{I} \sum_{j=1}^{J} \sum_{k=1}^{K} C\left[X_{i j k} a_{i}\right]-\sum_{i=1}^{I} \sum_{j=1}^{J} \sum_{k=1}^{K}\left[X_{i j k} b_{i}\right]
$$

where

$Z$ : Maximize of Profit.

$X_{i j k}$ : a tree i plants at location $(\mathrm{j}, \mathrm{k})$

$C:$ a carbon credit revenue (US\$/ton carbon)

$a_{i}$ : the ability of carbon dioxide absorb of tree $i$ (Ton carbon/year)

$b_{\mathrm{i}}$ : expenses of planting and maintenance tree $i$ (US\$/tree/year).

$i$ : tree species, where $i=1,2, \ldots, I$

$j$ : row array, where $j=1,2, \ldots, J$

$k$ : column array, where $k=1,2, \ldots, K$

Since the area for planting trees has been defined as 1 rai or equal to 1,600 square meter, by width and length of such area are 40 meter and 40 meter respectively. Moreover, the area has been divided into sub-area where suitable for planting tree must be 16 square meter per tree with width of 2 meter and length of 2 meter. From such defined areas for planting trees have resulted in the number of tree to be planted in the area of 1 rai is 400 trees totally which the position of each tree planting can be exhibited on $\mathrm{X}$-axis and $\mathrm{Y}$-axis.

\section{2) Constraints.}

The limitation is the range to determine value of result in objective equation that is very important data to determine the range of result calculated by using LINGO program. There are 5 limitations in this research, details are as following:

1) The total number of trees planting in specified area must not exceed than the number of trees that has been defined to plant in such area. This research has defined that the area of 1 rai can plant only 100 trees, so, the number of trees cannot exceed than defined number, for example there are suitable 5 tree species can be planted in the area of 1 rai including 80 Teaks (Tectona grandis L.f.), 60 Ma Kha num (Sindora siamensis Teijsm.ex Miq.), 60 Iron Wood (Hopea odorata Roxb.), 80 Burma Padouk (Pterocarpus macrocarpus Kurz), and 120 Bungor (Lagerstroemia calyculata Kurz). From the example found that the number of combined 5 tree species to be planted in the area of 1 rai is equal to 400 trees.

2) The number of trees in the same position can be only 1 tree, that means the same position or the same point where can plant any tree species, but can plant tree species only 1 tree, whether can say that the same position or the same point cannot plant the tree more than 1 tree. For example, there are 5 tree species can be planted in the same position including Teaks (Tectona grandis L.f.), Ma Kha num (Sindora siamensis Teijsm.ex Miq.), Iron Wood (Hopea odorata Roxb.), Burma Padouk (Pterocarpus macrocarpus Kurz), and Bungor (Lagerstroemia calyculata Kurz), but it is necessary to choose only 1 tree to be planted in such position.

3) Total amount of carbon dioxide that the trees can reduce them by uptake must not less than the amount of carbon dioxide that needs to be reduced. It can be explained that the reducing amount of carbon dioxide in the atmosphere from planting of trees 100 trees in the area of 1 rai must absorb carbon dioxide in the atmosphere at higher rate than minimum standard as specified. For example, the minimum standard of carbon dioxide uptake capacity in the area of 1 rai with 100 trees is $0.04375 \mathrm{TCO}_{2} \sim$ rai therefore 100 proper trees to be planted in the area of 1 rai should be able to absorb carbon dioxide from atmosphere greater than or equal to $0.04375 \mathrm{TCO}_{2} \sim /$ rai.

4) Tree species that are not conducive to growth or no encouraging each other will not be planted in the adjacent position, that means the trees to be planted in the adjacent position must support or encourage to growth and don't compete for water and foods each other, having growth rate at normal level on all tree species to be planted in the adjacent position, such as they should help to prevent insect pests, increase nutrient to other species, cover ground, increase income before harvesting, or on the other hand, don't choose tree species that are not conducive to growth or no encouraging each other to plant in the adjacent position.

5) The trees that can be planted in the area are represented by the number 1 , meanwhile the trees that cannot be planted in the area are represented by the number 0 . This means that the figures appeared in LINGO program from entering mathematical model to find the solution are 2 values as 0 and 1 , where 1 represents tree species that can be planted in such position and 0 represents tree species that cannot be planted 
in such position, for example using LINGO program to find solution found that the right position to plant Teaks (Tectona grandis L.f.) is value at 1 , this means that such position can plant Teaks (Tectona grandis L.f.), on the other hand, if found that the right position to plant Teaks (Tectona grandis L.f.) is value at 0 , this means that such position cannot plant Teaks (Tectona grandis L.f.).

This study is to determine the constraints equation of the problem which can be divided into 5 significant items that will help to determine the range of responses obtained from LINGO program which can be exhibited by mathematical symbols as follows:

1) The total number of trees planted in the specified area must not exceed the number of trees that can be planted in such area. The constraints of the problem can be represented in a symbolic mathematical equation (2)

$$
\sum_{i=1}^{I} \sum_{j=1}^{J} \sum_{k=1}^{K} X_{i j k} S_{i} \leq A
$$

where $s_{i}$ is the area required to plant tree $i$ and $A$ is a total available area.

2) The number of tree planted in the same position is only one tree, cannot plant more than one tree in the same position. Or may be said that in a position to plant any tree species can be planted only 1 tree. The constraints of the problem can be represented in a symbolic mathematical equation (3)

$$
\sum_{i=1}^{m} X_{i j k}=1 ; \forall j, k
$$

3) Total amount of carbon dioxide the can be reduced by uptake of trees will not be less than the amount of carbon dioxide that need to reduce. The percentage of such carbon dioxide reduction would be compared to the amount of carbon dioxide that had occurred in Thailand according to the base year. The constraints of the problem can be represented in a symbolic mathematical equation (4)

$$
\sum_{i=1}^{I} \sum_{j=1}^{J} \sum_{k=1}^{K} X_{i j k} \mathrm{a}_{i} \geq L
$$

where $l$ is an amount of required carbon sequestration

4) Tree species that are not conducive to growth or no encouraging each other will not be planted in the adjacent position due to they will compete for water and food each other. The constraints of the problem can be represented in a symbolic mathematical equation (5)

$$
X_{i j k}+X_{i m n}=1 \quad ; \forall \mathrm{i},
$$

where $m \in\{j-1, j, j+1\}, n \in\{k-1, k, k+1\}$

5) The trees that can be planted in the area are represented by the number 1 , meanwhile the trees that cannot be planted in the area are represented by the number 0 . The constraints of the problem can be represented in a symbolic mathematical equation (6)

$$
X_{i j k}=0,1 \quad ; \forall \mathrm{i}, \mathrm{j}, \mathrm{k}
$$

\section{B. Experimentation}

Once the mathematical model is developed, the verification will be next. The input data such as operating expenses and carbon sequestration must be researched and collected as shown in Table I and Table II respectively. The

\begin{tabular}{|c|c|c|}
\hline Legend & Tree & Absorption $\mathrm{CO}_{2}$ \\
\hline & Pterocarpus macrocarpus Kurz & 544.11 \\
\hline & $\begin{array}{l}\text { Anthocephalus chinensis (Lam) A. Rich. } \\
\text { ex Walp. }\end{array}$ & 358.13 \\
\hline & Azadirachta indicavar. siamensis Valeton & 322.22 \\
\hline & Acacia mangium Willd. & 173.75 \\
\hline & $\begin{array}{l}\text { Azadirachta.indica.A...Juss } \\
\text { Var. siamensis }\end{array}$ & 221.78 \\
\hline & Swietenia macrophylla King & 143.16 \\
\hline & Avicennia marina (Forsk.) Vierh & 251.67 \\
\hline & Eucalyptus citriodara. & 302.54 \\
\hline & Aegle marmelos (L.) Correa. Ex Roxb. & 274.32 \\
\hline & Lagerstroemia calyculata Kurz & 508.01 \\
\hline
\end{tabular}
flow diagram[11], [12]

TABLE I: THE OPERATING AND MAINTENANCE EXPENSES

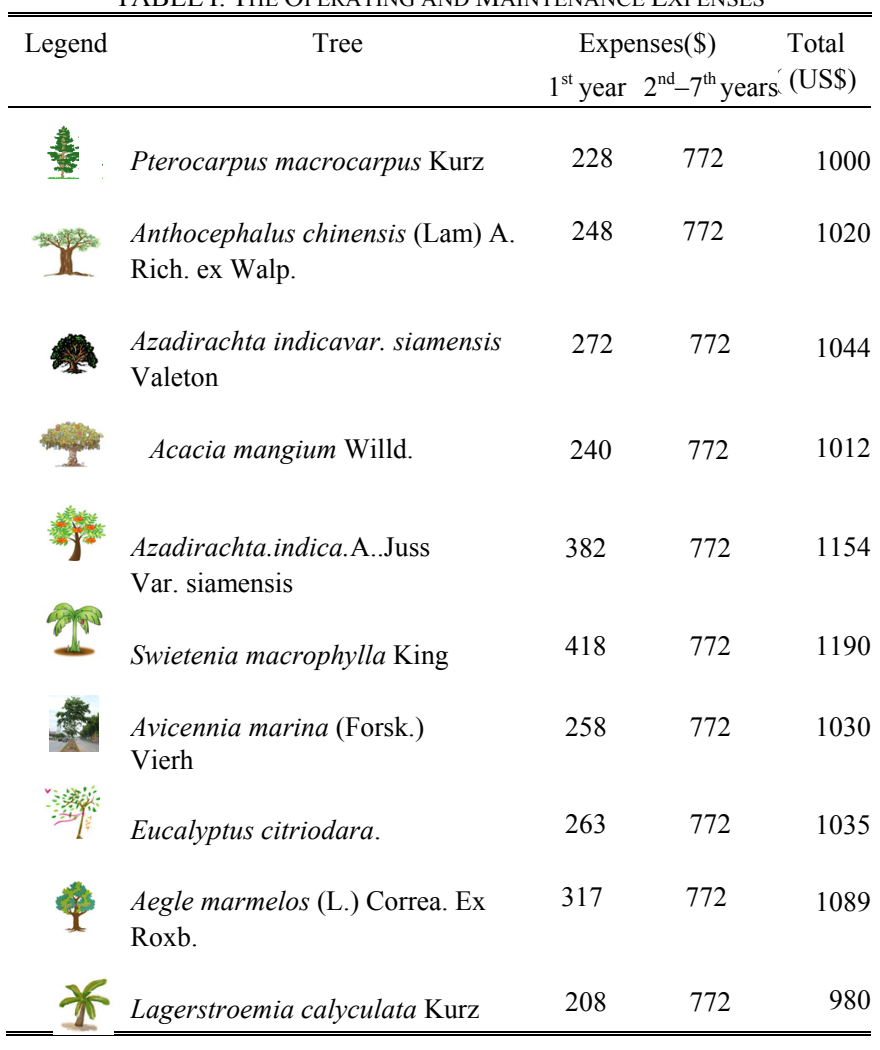

TABLE II: The CARbon SeQuestered by a Tree (Ton CO 2 Per Year)

The planting area of 400 by 400 meter is used in the model. The required area of each plant to be fully grown is designed at 2 by 2 meter which provides the best result. Therefore, there will be exact 400 trees need to grow in the area. 


\section{Results}

Planting trees to absorb carbon dioxide up to the amount required are needed to consider the appropriate tree species planted in one unit area and those trees can grow well in Nonthaburi. Finding the right mathematical solution will enable to know the maximum profit occurred from selling of carbon credit after deducted all expenses related to the trees. Enter data into LINGO software; propose the obtained results by region in symbolical picture according to details as follows:

Nonthaburi has determined the economic tree group of 10 species to study, include Pterocarpus macrocarpus Kurz, Anthocephalus chinensis (Lam) A. Rich. ex Walp., Azadirachta indicavar. siamensis Valeton, Acacia mangium Willd, Azadirachta.indica.A..Juss Var siamensis, Swietenia macrophylla King, Avicennia marina (Forsk.) Vierh, Eucalyptus citriodara, Aegle marmelos (L.) Correa. Ex Roxb, Lagerstroemia calyculata Kurz. There are related data include the list of tree, carbon dioxide uptake capacity, expense, and carbon credit price that are the data entered into mathematical equation designed by LINGO program. The details of input data of those economical trees are expressed in Table III.

TABLE III: THE OPTIMAL SOLUTION OF NONTHABURI

\begin{tabular}{|c|c|c|c|c|}
\hline \multirow[b]{2}{*}{ No. } & \multirow[b]{2}{*}{$\begin{array}{l}\text { Science Name of Tree } \\
\text { in Nonthaburi Province }\end{array}$} & \multicolumn{3}{|c|}{ Input Data } \\
\hline & & $\begin{array}{c}\text { Adsorption } \\
\mathrm{CO}_{2} \\
\mathbf{T C O}_{2} \sim / \mathbf{y} \\
\end{array}$ & $\begin{array}{c}\text { Charges } \\
\text { (US\$) }\end{array}$ & $\begin{array}{c}\text { Carbon } \\
\text { Credit } \\
\text { (US\$) }\end{array}$ \\
\hline 1. & $\begin{array}{l}\text { Pterocarpus macrocarpus } \\
\text { Kurz }\end{array}$ & 544.11 & 1000 & 10.39 \\
\hline 2. & $\begin{array}{l}\text { Anthocephalus chinensis (Lam) } \\
\text { A. Rich. ex Walp. }\end{array}$ & 358.13 & 1020 & 10.39 \\
\hline 3. & $\begin{array}{l}\text { Azadirachta indicavar. } \\
\text { siamensis Valeton }\end{array}$ & 322.22 & 1044 & 10.39 \\
\hline 4. & Acacia mangium Willd. & 173.75 & 1012 & 10.39 \\
\hline 5. & $\begin{array}{l}\text { Azadirachta.indica.A. Juss } \\
\text { Var. siamensis }\end{array}$ & 221.78 & 1154 & 10.39 \\
\hline 6. & Swietenia macrophylla King & 143.16 & 1190 & 10.39 \\
\hline 7. & Avicennia marina (Forsk.) Vierh & 251.67 & 1030 & 10.39 \\
\hline 8. & Eucalyptus citriodara. & 302.54 & 1035 & 10.39 \\
\hline 9. & $\begin{array}{l}\text { Aegle marmelos (L.) Correa. Ex } \\
\text { Roxb. }\end{array}$ & 274.32 & 1089 & 10.39 \\
\hline 10. & Lagerstroemia calyculata Kurz & 508.01 & 980 & 10.39 \\
\hline
\end{tabular}

Input Data of Nonthaburi in Table III were used in mathematical equation according to specified, such as objective equation and constrains equation of the problem. From such input data result in LINGO program showed the results of appropriate trees as Table IV

The result from data input into LINGO software (Table IV), the results of appropriate tree planting are 4 species in the area of 1 rai of Nonthabure, found that the number of tree planting of Pterocarpus macrocarpus Kurz, Anthocephalus chinensis (Lam) A. Rich. ex Walp., Azadirachta.indica.A..Juss Var. siamensis and Aegle marmelos (L.) Correa. Ex Roxb. are 120, 80, 100 and 100 trees respectively. Planting positions are expressed in Table IV. The obtained benefit from planting trees according to such plan is US\$ 73,261 within 7 years.

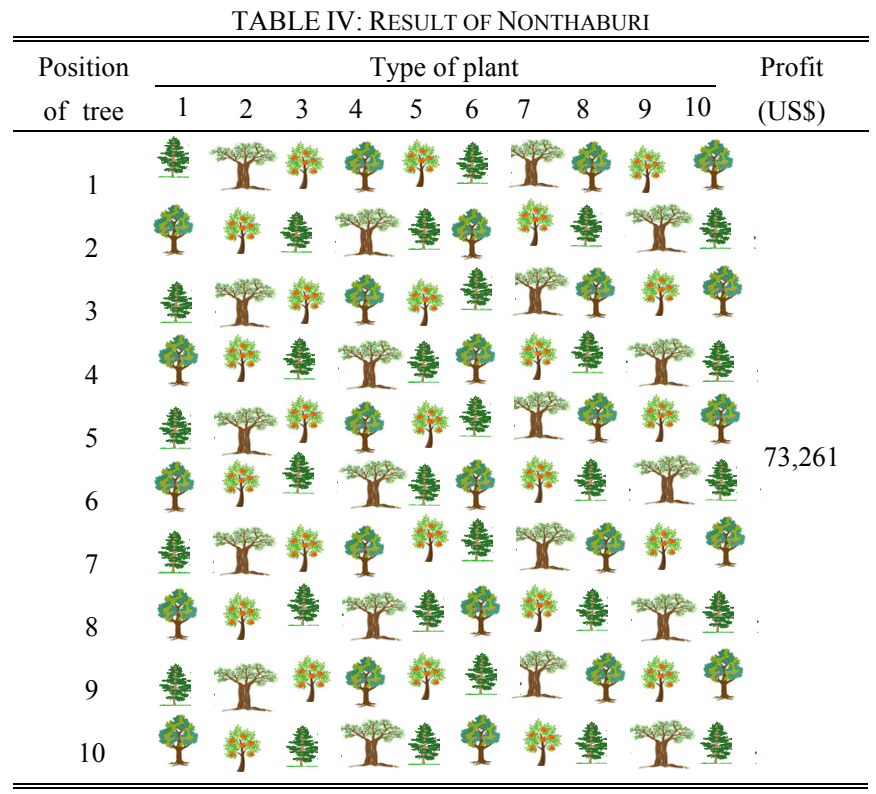

\section{CONCLUSION}

The object of this study is to generate Optimization Mathematical Model for finding the right number and tree species that should be planted in one unit area in order to reduce the amount of carbon dioxide to the amount as required and to gain maximum profit by using Integer Linear Programming.

The study result and data gathering of each tree species that have carbon dioxide uptake capacity, have been classified by region, including cost and economic returns. Selling-Buying prices of Carbon Credit during 2009-2012 were used to calculate coefficients in a mathematical equation in order to find the solution of appropriate tree species planted in one unit area and maximize profit by selling carbon credit, classified by region as follows:

The study of 10 tree species that can grow well on the Nonthaburi area, include Pterocarpus macrocarpus Kurz, Anthocephalus chinensis (Lam) A. Rich. ex Walp., Azadirachta indicavar. siamensis Valeton, Acacia mangium Willd, Azadirachta.indica.A..Juss Var. siamensis, Swietenia macrophylla King, Avicennia marina (Forsk.) Vierh, Eucalyptus citriodara, Aegle marmelos (L.) Correa. Ex Roxb, Pterocarpus macrocarpus Kurz. has highest uptake capacity of carbon dioxide, that is $544.11 \mathrm{TCO}_{2} /$ year/rai and Swietenia macrophylla King has lowest uptake capacity of carbon dioxide, that is $143.16 \mathrm{TCO}_{2} /$ year/rai. Key all gathered data, such as $\mathrm{CO}_{2}$ uptake capacity, cost, carbon credit buying-selling price, into LINGO software to find the most appropriate number and tree species that should be planted in one unit area, foundthat there are 4 appropriate tree species, include Pterocarpus macrocarpus Kurz, Anthocephalus chinensis (Lam) A. Rich. ex Walp., Azadirachta.indica. A..Juss Var. siamensis and Aegle marmelos (L.) Correa. Ex Roxb and the appropriate number in the area of 1 rai of each tree species are 120,80, 100 and 100 respectively. The 
benefits from tree planting on plan are US\$ 73,261 in 7 years.

\section{DISCUSSION}

The study result gained from calculation of the appropriate number and tree species planted to absorb carbon dioxide in each region, found that the planted trees can reduce carbon dioxide emitted to atmosphere as follows:

Nonthaburi Province.

The study results from calculation by using LINGO software found that when plant 120 Pterocarpus macrocarpus Kurz, 80 Anthocephalus chinensis (Lam) A. Rich. ex Walp., 100 Azadirachta.indica.A..Juss Var. siamensis and 100 Aegle marmelos (L.) Correa. Ex Roxb in the area of 1 rai, the total uptake capacity of carbon dioxide of all those tree species are equal to $143.553 \mathrm{TCO}_{2} /$ year/rai, but under Kyoto Protocol to the United Nations Framework Convention on Climate Change has asked for cooperation to reduce carbon dioxide by $5 \%$ compared to the amount of base year 1990 (IPCC, 2007), in which such base year had carbon dioxide $280 \mathrm{MTCO}_{2} /$ year in Thailand, together with the total area in Thailand are 320 million rai therefore the minimum carbon dioxide reduction in Nonthaburi $(388,939.38$ rai) will be $340,321.95 \mathrm{TCO}_{2} /$ year/sector, how to calculate are as follows:

$\begin{array}{ll}=\frac{(388,939.38 \mathrm{rai}) \times\left(280 \mathrm{MTCO}_{2} / \text { year }\right) \times(5 \%)}{\left(320 \times 10^{6} \mathrm{rai}\right)} & \\ =388,939.38 \times 0.04375 & \mathrm{TCO}_{2} / \text { year } / \text { sector } \\ =340,321.95 & \mathrm{TCO}_{2} / \text { year } / \text { sector }\end{array}$

In order to have carbon dioxide uptake capacity up to the amount calculated from reforestation by the given pattern, so, the campaign for reforestation by the given pattern at least 2,370.71 rai should be done.

This paper demonstrates the utilization of the optimization technique to determine a number and type of trees to be planted in the forest in order to maximize profit. According to the result, it can be seen that the tree distribution is quite even and it is considered to be practical. This mathematical model will be one of the tools used in forestation in order to obtain required amount of carbon sequestration in the CDM project.

\section{RESEARCH IN THE FUTURE}

1) The study of the way of cropping by using mathematical program to define proper planting pattern for various organizations in the CDM project. Especially the economic crops that that introduce revenues from export into the country, such as rice, sugar cane, and rubber tree. Rice cultivation is the main occupation of the majority of farmers and Thailand had been the world largest exporter of rice throughout the year 1980-2011 and was ranked third behind Vietnam and India in the year 2012 (Office of Agricultural Economics, 2012). Not only other research that study the way of planting to maximize productivity with quality output to which introduce a steady income to the country, but also the environmental maintenance by reducing carbon dioxide from cropping should be considered. The appropriate cropping for greatest reduction of carbon dioxide emission including increasing income from selling carbon credit can use mathematical program to define the appropriate planting pattern.

2) The study of the way to evaluate carbon dioxide uptake capacity in order to indicate the highest level of carbon dioxide that the planting of forestry plantations in each area of Thailand can absorb. From such way can use mathematical model to calculate maximum carbon dioxide $\left(\mathrm{CO}_{2}\right)$ absorption that can be happened in the area of the forestry plantation planting.

\section{REFERENCES}

[1] F. Wagner, B. Aaby, and H. Visscher, "Rapid atmospheric $\mathrm{CO}_{2}$ changes associated with the 8,200-years-B.P. cooling event," in Proc. of the National Academy of Sciences of the United States of America. vol.99, no.19, pp. 12011-12014, 2002.

[2] K. Capoor and P. Ambrosi, State and trends of the carbon market, World Bank Institute Washington D.C., May, 2008, p p.19.

[3] S. Damilola and S. Olawuyi, "From Kyoto to Copenhagen: Rethinking the place of flexible mechanisms in the Kyoto Protocol's post 2012 commitment period," Law, Environment and Development Journal, vol. 6, no. 1, pp.21-35, 2010.

[4] M. P. Cigran and P. Iturregui, "Strategy to promote the clean development mechanism in Peru," UNEP Riso Centre, Denmark, 2004, pp. 64.

[5] K. Steppe, D. J. W. De Pauw, R. Lemeur and P. A. Vanrolleghem, “A mathematical model linking tree sap flow dynamics to daily stem diameter fluctuations and radial stem growth," Oxford Journals, Life Sciences, Tree Physiology, vol. 26, issue 3, pp. 257-273, 2006.

[6] N. Boland, "Solving environmental problems with integer programming recent experience and challenges," in Proc. The 18th World IMACS Congress and MODSIM09 International Congress on Modelling and Simulation, Cairns, Australia from July13-17. pp. 1-12, 2009.

[7] R. Jain, J. Vaughan, K. Heitkamp, C. Ramos, C. Claiborn, M. Schreuder, M. Schaa, and B. Lamb, "Development of the Clear Sky Smoke Dispersion Forecast System for Agricultural Field Burning in the Pacific Northwest," Atmospheric Environment, pp. 41, pp. 6745-6761, 2007.

[8] C. Vanlisuta and S. Prombanpong,"The Research framework for a reduction of global warming through efficient afforestation and reforestation in thailand," in Proc. of $11^{\text {th }}$ Asia Pacific Industrial Engineering and Management Systems Conf., Malaka, Malaysia, 6-9 December, 2010, pp.115-119.

[9] C. Vanlisuta and S. Prombanpong, "An integer programming approach to optimize the plantation in order to reduce global warming,“ Advanced Materials Research, vol. 548, pp. 686-690, 2012.

[10] P. Kramer, J. Kozlowski, and T. Theodore, Physiology of woody plants, New York: Academic Press, p. 81, 1979.

[11] S. Kerdkankankaew, and V. Saosiri, Hand book of Domistic trees and their sequestered, Office of Nation Resources and Environmental Policy and Planning, Ministry of Natural Resources and Environment, 2009.

[12] R. A. Birdsey, "Carbon storage and accumulation in United States forest ecosystem," General technical report WO (USA), U.S. Dept. of Agriculture, Forest Service, pp.11-51, 1992.

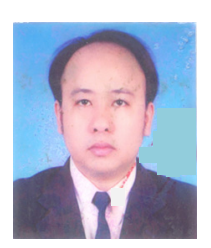

Chanchai Vanlisuta is a lecturer at Faculty of Industrial Technology, Phranakhon Rajabhat University, Thailand. He received a Master Degree from the Graduate School of Engineering at King Mongkut's University of Technology Thonburi, His teaching and research interests include work study and planning and control production. 